\title{
Liquisolid technique as a tool for enhancement of poorly water-soluble drugs and evaluation of their physicochemical properties
}

\author{
YOUSEF JAVADZADEH ${ }^{1}$ \\ MOHAMMAD REZA SIAHI ${ }^{1}$ \\ SOLMAZ ASNAASHARI ${ }^{1}$ \\ ALI NOKHODCHI ${ }^{1,2, *}$ \\ ${ }^{1}$ Drug Applied Research Center \\ and Faculty of Pharmacy \\ Tabriz University of Medical Sciences \\ Iran \\ ${ }^{2}$ Medway School of Pharmacy \\ Central Ave., University of Kent and \\ Greenwich, Chatham, Kent, ME4 4TB \\ United Kingdom
}

Accepted January 9, 2007
The potential of liquisolid systems to improve the dissolution properties of a water-insoluble agent (indomethacin) was investigated. In this study, different formulations of liquisolid tablets using different co-solvents (non-volatile solvents) were prepared and the effect of aging on the dissolution behaviour of indomethacin liquisolid compacts was investigated. To evaluate any interaction between indomethacin and the other components in liquisolid formulations, X-ray powder diffraction (XPD) and differential scanning calorimetry (DSC) were used. Dissolution test was carried out at two different $\mathrm{pH}, 1.2$ and 7.2 , to simulate the stomach or intestine fluid, respectively. The results showed that liquisolid formulations exhibited significantly higher drug dissolution rates at $\mathrm{pH} 1.2$ and 7.2 compared to compacts prepared by the direct compression technique. The enhanced rate of indomethacin dissolution from liquisolid tablets was probably due to an increase in wetting properties and surface area of drug particles available for dissolution. In order to investigate the effect of aging on the hardness and dissolution rate of liquisolid compacts, the formulations were stored at 25 ${ }^{\circ} \mathrm{C} / 75 \%$ relative humidity for a period of 12 months. The results showed that aging had no significant effect on dissolution profiles of liquisolid tablets. Liquisolid compacts containing propylene glycol as vehicle produced higher dissolution rates in comparison with liquisolid compacts containing PEG 400 or Tween 80 of the same concentration. The DSC and XPD results showed no changes in crystallinity of the drug and interaction between indomethacin and excipients (Avicel and silica) during the process.

Keywords: indomethacin, liquisolid compacts, dissolution rate, aging, DSC, XPD

\footnotetext{
* Correspondence, e-mail: a.nokhodchi@kent.ac.uk
} 
Y. Javadzadeh et al.: Liquisolid technique as a tool for enhancement of poorly water-soluble drugs and evaluation of their physicochemical properties, Acta Pharm. 57 (2007) 99-109.

Poorly water-soluble drugs (such as indomethacin) involve many difficulties in the development of pharmaceutical dosage forms for oral delivery systems due to their low bioavailability. It has been established that the active ingredient in a solid dosage form must undergo dissolution before it is available for absorption from the gastrointestinal tract. The rate of absorption of a poorly water-soluble drug, formulated as an orally administered solid dosage form, is controlled by its dissolution rate in the fluid present at the absorption site, i.e., the dissolution rate is often the rate-determining step in drug absorption. Therefore, the solubility and dissolution behavior of a drug are the key determinants of its oral bioavailability. Many methods are available to improve these characteristics, including (i) reducing the particle size to increase surface area, thus increasing the drug dissolution rate; (ii) solubilization in surfactant systems; (iii) formation of water-soluble complexes; (iv) use of pro-drug and drug derivatization such as strong electrolyte salt forms that usually have higher dissolution rates; and $(v)$ manipulation of the solid state of a drug substance to improve drug dissolution, i.e., by decreasing crystallinity of the drug substance through formation of solid solutions (1). The most common method is to increase the drug surface area by micronization. But, in practice, the effect of micronization is often disappointing, especially when the drugs are encapsulated or tableted (2-4). The most promising method for promoting dissolution is the formation of liquisolid tablets (5-7).

Formulating liquid medications into solid compacts has been the object of many studies. Jarowski $(8,9)$ and Spireas et al. $(5-7)$ worked on producing solid solutions and »liquisolids « based on the concept of blending liquid medications with selected powder excipients to produce free flowing, readily compressible powders.

A »liquisolid system « refers to formulations formed by conversion of liquid drugs, drug suspensions or drug solution in non-volatile solvents, into dry, nonadherent, free-flowing and compressible powder mixtures by blending the suspension or solution with selected carriers and coating materials (5). Various grades of cellulose, starch, lactose, etc., may be used as the carrier, whereas very fine particle size silica powder may be used as the coating material.

The anti-inflammatory agent indomethacin exhibits poor solubility. This undesirable physical property may increase the incidence of irritating side effects on the gastrointestinal tract because of a prolonged contact time with the mucosa. In our previous study (10), it was shown that indomethacin liquisolid compacts demonstrated considerably higher drug dissolution rate than those of conventional capsules and directly compressed tablets. In this study, the effects of aging and types of vehicle on the hardness and dissolution profile of indomethacin liquisolid compacts were investigated. Interaction between the drug and excipients, and crystalinity changes, if any, in liquisolid formulations were also studied using X-ray powder diffraction (XPD) and differential scanning calorimetery (DSC).

\section{EXPERIMENTAL}

\section{Materials}

Indomethacin was provided by Industrial Shahid Razakani (Iran). Coarse granular microcrystalline cellulose (Mingtai Chemical, Taiwan), sodium starch glycolate (Yung 
Y. Javadzadeh et al.: Liquisolid technique as a tool for enhancement of poorly water-soluble drugs and evaluation of their physicochemical properties, Acta Pharm. 57 (2007) 99-109.

Zip Chemical, Taiwan), nm-sized amorphous silicon dioxide (Mingtai Chemical) and Tween 80, lactose, starch, sorbitol and sodium chloride (Merck, Germany) were used.

\section{Spectrophotometric analysis}

The spectrophotometric analysis of all indomethacin samples in aqueous solutions ( $\mathrm{pH} 1.2$ or 7.2) was performed at $318 \mathrm{~nm}$ (UV/Visible spectrophotometer, Shimadzu-120, Japan). Standard curves were constructed by serially diluting an aqueous stock solution of the drug (at $\mathrm{pH} 1.2$ and 7.2) to obtain concentrations in the range of $2.5-50 \mu \mathrm{g} \mathrm{mL}^{-1}$ using simulated gastric fluid (SGF) or simulated intestine fluid (SIF) as diluents. Each sample was analyzed in triplicate.

\section{Preparation of conventional tablet and liquisolid compacts}

Indomethacin conventional tablets were produced by mixing the drug ( $2.5 \mathrm{~g})$ with a microcrystalline cellulose-silica mixture (ratio of microcrystalline cellulose/silica was 20:1 and the amounts of microcrystalline cellulose and silica were $10 \mathrm{~g}$ and $0.5 \mathrm{~g}$, respectively) for a period of $10 \mathrm{~min}$ in a small cubic mixer. The mixture was mixed with sodium starch glycolate (as disintegrating agent) for $10 \mathrm{~min}$, and compressed on a 10-mm punch and die using a manual-tableting machine (Riken, Japan). Sufficient compression load was applied in order to produce tablets with the hardness of $42-56 \mathrm{~N}$. This formulation was denoted as DCT. The same formulation was usual to produce capsule formulation for comparison purposes. Then each tablet and capsule contained $25 \mathrm{mg}$ indomethacin, $100 \mathrm{mg}$ microcrystalline cellulose, $5 \mathrm{mg}$ of nm-sized silica and $5 \mathrm{mg}$ sodium starch glycolate.

Several liquisolid compacts (denoted ILS-1 to ILS-3) were prepared as follows. Indomethacin $(20 \mathrm{~g})$ was dispersed in a nonvolatile vehicle (propylene glycol, Tween 80 or PEG 400). Then a binary mixture of carrier-coating materials (microcrystalline cellulose as the carrier powder and silica as the coating material at a ratio of 20:1) was added to the mixture containing the drug and propylene glycol under continuous mixing in a mortar. Depending upon the type of vehicle in the formulation, different liquid loading factors were employed in our liquisolid preparations (the liquid loading factor, $\mathrm{L}_{\mathrm{f}}$, is the mass ratio of the liquid medication and carrier powder in the liquidsolid formulation). Therefore, different concentrations of avicel and silica were used to prepare different liquisolid formulations. For example, to prepare different batches of liquisolid powders, the amounts of avicel were 418, 476.2 and $444.4 \mathrm{~g}$ mixed with 20.9, 23.8, and $22.22 \mathrm{~g}$ silica for ILS-1, ILS-2 and ILS-3, respectively. Finally, 5\% $(\mathrm{m} / \mathrm{m})$ of sodium starch glycolate, as disintegrant, was mixed with the mixture for a period of $10 \mathrm{~min}$. The final mixture was compressed using the manual tableting machine to achieve tablet hardness of 42-56 N. Important formulation characteristics of the prepared indomethacin liquisolid compacts are shown in Table I.

\section{Dissolution studies}

The USP paddle method was used for all the in vitro dissolution studies (11). Water containing $\mathrm{HCl}$, which simulated gastric fluid without pepsin $(\mathrm{pH}$ 1.2) or intestinal fluid without pancreatin (phosphate buffer $\mathrm{pH}$ 7.2), were used as dissolution media. The rate of 
Y. Javadzadeh et al.: Liquisolid technique as a tool for enhancement of poorly water-soluble drugs and evaluation of their physicochemical properties, Acta Pharm. 57 (2007) 99-109.

Table I. Key formulation characteristics of the prepared indomethacin liquisolid compacts

\begin{tabular}{cccccc}
\hline $\begin{array}{c}\text { Liquisolid } \\
\text { system }\end{array}$ & $\begin{array}{c}\text { Non-volatile } \\
\text { solvent }\end{array}$ & Carrier & $\begin{array}{c}\text { Drug concentration } \\
\text { in liquid medication } \\
(\%, m / m)\end{array}$ & $\begin{array}{c}\text { Liquid load } \\
\text { factor }\left(\mathrm{L}_{\mathrm{f}}\right)\end{array}$ & $\begin{array}{c}\text { Unit dose } \\
(\mathrm{mg})\end{array}$ \\
\hline ILS-1 & Propylene glycol & Avicel & 20 & 0.240 & 707.2 \\
ILS-2 & Tween 80 & Avicel & 20 & 0.210 & 789.4 \\
ILS-3 & PEG 400 & Avicel & 20 & 0.225 & 745.6 \\
\hline
\end{tabular}

stirring was $100 \pm 2 \mathrm{rpm}$. The amount of indomethacin was $25 \mathrm{mg}$ in all formulations. The dosage forms were placed in $900 \mathrm{~mL}$ of gastric fluid ( $\mathrm{HCl}$ solution) or intestinal fluid (phosphate buffer $\mathrm{pH} 7.2)$ and maintained at $37 \pm 0.1{ }^{\circ} \mathrm{C}$. At appropriate intervals $(10,20,30$ and $60 \mathrm{~min}), 5 \mathrm{~mL}$ of the samples were taken and filtered through a $0.45 \mathrm{~mm}$ Millipore filter. The dissolution medium was then replaced by $5 \mathrm{~mL}$ of fresh dissolution fluid to maintain a constant volume. The samples were then analyzed at $318 \mathrm{~nm}$. The mean of 3 determinations was used to calculate the drug release from each formulation.

For assessment and comparison of dissolution profiles, the similarity factor $\left(f_{2}\right)(12)$ was calculated. Results are quoted as significant where $\mathrm{f}_{2}<50$.

To compare the effects of the type of cosolvent on the drug release, mean dissolution time $(M D T)(13)$ and dissolution efficiency $(D E)(14)$ were used. Mean dissolution time is as described below:

$$
M D T=\frac{\sum_{j=1}^{n} t \Delta M_{j}}{\sum_{j=1}^{n} \Delta M_{j}}
$$

where $j$ is the sample number, $n$ is the number of dissolution sample times, $t$ is the time at the midpoint between $t$ and $t-1$ (easily calculated with $(t+t-1) / 2$ ) and $\Delta M_{j}$ is the additional amount of drug dissolved between $t$ and $t-1$.

$D E$ is as described below:

$$
D E=\frac{\int_{0}^{t} Y \times d t}{Y_{100} \times t} \times 100 \%
$$

where $Y$ is the percent drug released as a function of time, $t$ is the total time of drug release and $Y_{100}$ is $100 \%$ drug release.

\section{$X$-ray powder diffraction}

The cavity of the metal sample holder of the X-ray diffractometer was filled with ground sample powder and then smoothed with a spatula. X-ray diffraction pattern of 
Y. Javadzadeh et al.: Liquisolid technique as a tool for enhancement of poorly water-soluble drugs and evaluation of their physicochemical properties, Acta Pharm. 57 (2007) 99-109.

indomethacin samples was obtained using the X-ray diffractometer (Siemens, Model D5000, Germany) at $40 \mathrm{kV}, 30 \mathrm{~mA}$ and a scanning rate of $0.6 \mathrm{~min}^{-1}$ over the range 5-70 20, using $\mathrm{CuK} \alpha 1$ radiation of wavelength $1.5405 \AA$.

\section{Differential scanning calorimetry}

Thermograms of samples (indomethacin, excipients physical mixtures of conventional formulations and liquisolid formulations) were recorded on a DSC-60 (Shimadzu, Japan). Samples (3-5 mg accurately weighed to $0.005 \mathrm{mg}$ ) were placed in aluminum pans and the lids were crimped using a Shimadzu crimper. Thermal behavior of the samples was investigated at a scanning rate of $10{ }^{\circ} \mathrm{C} \mathrm{min}-1$, covering a temperature range of 30 $300{ }^{\circ} \mathrm{C}$. The instrument was calibrated with an indium standard.

\section{Statistical analysis}

All the data were statistically analyzed using a $t$-test of unknown variance.

\section{RESULTS AND DISCUSSION}

To investigate the effect of vehicle type on the rate of indomethacin dissolution from liquisolid compacts, several formulations were prepared with polyethylene glycol (ILS-1), Tween 80 (ILS-2) and PEG 400 (ILS-3) containing 20\% $(\mathrm{m} / \mathrm{m})$ of indomethacin in liquid medication. The dissolution profiles of these liquisolid compacts at different $\mathrm{pH}$ (1.2 and 7.2) are shown in Fig. 1. It can be seen from Fig. 1 that all three liquid medications (PG, Tween 80 and PEG 400) used in liquid solid compacts, are able to increase the dissolution rate of indomethacin from liquisolid compacts in comparison with the conventional tablet (DCT) or capsule formulations. According to Fig. 1, liquisolid compacts containing propylene glycol produced higher dissolution rates compared to other liquisolid compacts containing PEG 400 or Tween 80 of the same concentration. For example, amounts of the drug released from formulations in $10 \mathrm{~min}$ in the presence of PG, PEG 400 or Tween 80 were 34, 28 and 27 and 99,90 and $87 \%$ at pH 1.2 and 7.2, respectively. This is due to different solubility of indomethacin in liquid medications (10).

To compare the dissolution data, dissolution efficiency $(D E)$ and mean dissolution time $(M D T)$ were used. The results of fitting the dissolution data with these dissolution criteria are shown in Table II. The values of $D E$ are consistent with the dissolution data. For example, the $D E$ values for the conventional tablets and capsules at $\mathrm{pH} 1.2$ are 8.9 and $10.4 \%$, respectively, whereas this value increased to $35.8,32.2$ and $30.0 \%$ for liquisolid compacts containing PG, PEG 400 and Tween 80, respectively. A similar trend was obtained at $\mathrm{pH}$ 7.2. The results show that within the formulation series $D E$ values increased as the $\mathrm{pH}$ of the dissolution medium increased. This is due to higher indomethacin solubility at higher $\mathrm{pH}$. Table II also shows that MDT was considerably lower for the liquisolid formulation, indicating a faster dissolution rate for these formulations compared to the conventional formulations.

It has been shown that polymorphic changes of the drug are important factors, which may affect the dissolution rate and bioavailability (15). It is therefore important to study 
Y. Javadzadeh et al.: Liquisolid technique as a tool for enhancement of poorly water-soluble drugs and evaluation of their physicochemical properties, Acta Pharm. 57 (2007) 99-109.
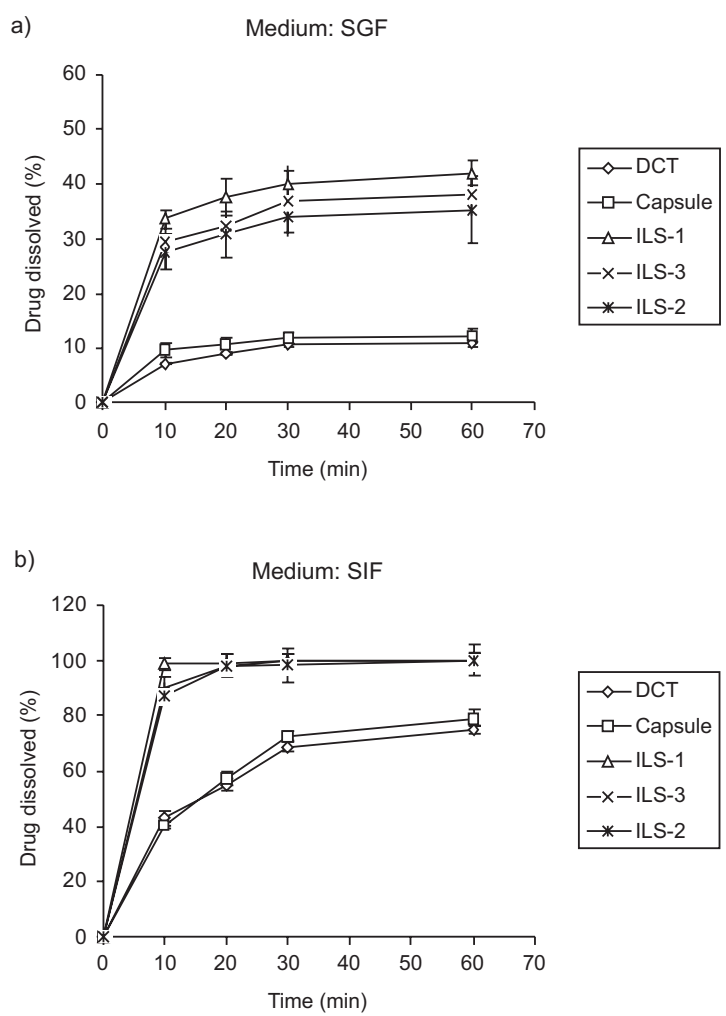

Fig. 1. Effect of the type of vehicle on the dissolution profile of indomethacin liquisolid compacts (mean $\pm \mathrm{SD}, n=3$ ).

the polymorphic changes of indomethacin in liquisolid formulations. Fig. 2 shows the X-ray diffractograms of pure indomethacin and pure excipients, a physical mixture of the conventional formulation (indomethacin, avicel and silica) and liquisolid formula-

Table II. Mean dissolution time (MDT) and dissolution efficiency (DE) of liquisolid formulations and conventional formulations

\begin{tabular}{ccccc}
\hline \multirow{2}{*}{ Formulation code } & \multicolumn{2}{c}{ DE (\%) } & \multicolumn{2}{c}{ MDT (min) } \\
\cline { 2 - 5 } & $\mathrm{pH} \mathrm{1.2}$ & $\mathrm{pH} \mathrm{7.2}$ & $\mathrm{pH} \mathrm{1.2}$ & $\mathrm{pH} \mathrm{7.2}$ \\
\hline DCT & 8.9 & 58.0 & 11.0 & 13.6 \\
Capsule & 10.4 & 60.3 & 9.3 & 14.3 \\
LS-1 & 35.8 & 91.2 & 9.0 & 5.2 \\
LS-2 & 32.2 & 88.7 & 9.6 & 6.2 \\
LS-3 & 30.0 & 88.6 & 9.2 & 6.8 \\
LS-1-aged $^{\text {a }}$ & 37.2 & 92.1 & 8.1 & 5.1 \\
\hline
\end{tabular}

a LS-1 stored at $25^{\circ} \mathrm{C} / 75 \%$ relative humidity for a period of 12 months. 
Y. Javadzadeh et al.: Liquisolid technique as a tool for enhancement of poorly water-soluble drugs and evaluation of their physicochemical properties, Acta Pharm. 57 (2007) 99-109.

tion. Indomethacin diffractogram showed sharp peaks at 10.2, 11.6, 17.0, 19.6, 20.8, 21.8, 24.0, 26.2 and $29.52 \theta$. This corresponds to the $\gamma$ polymorph of indomethacin (16-19). As it is clear from Fig. 2, liquisolid and physical mixture formulations have the same diffraction pattern and there were no peaks other than the peaks of avicel and indomethacin. It was shown that two environmental factors (temperature and relative humidity) can alter the crystal form of indomethacin $(20,21)$. Below $T_{\mathrm{g}}$ of indomethacin, only the most stable $\gamma$-crystal form of indomethacin appeared, whereas above $T_{\mathrm{g}}$, both the unstable $\alpha$-crystal form and the $\gamma$-form appeared, with the $\alpha$-form dominating as the temperature was raised above $60{ }^{\circ} \mathrm{C}$. Imaizumi et al. (21) reported that the exposure of indomethacin to 69 and $79 \% \mathrm{RH}$ produced only $\gamma$-crystal forms, whereas exposure to $89 \% \mathrm{RH}$ produced a mixture of $\alpha$ - and $\gamma$-forms and $100 \%$ RH produced the $\alpha$-form only. The results showed that $T_{\mathrm{g}}$ of indomethacin in the present study was $42{ }^{\circ} \mathrm{C}$, which is well above the preparation conditions of liquisolid powders $\left(25^{\circ} \mathrm{C} / 60 \% \mathrm{RH}\right)$ in this study. As the liquisolid compacts were prepared at $25{ }^{\circ} \mathrm{C} / 60 \% \mathrm{RH}$, so according to the above information, it is unlikely that these conditions would convert the $\gamma$-form to $\alpha$-form.

DSC thermograms confirmed the above findings (Fig. 3). Indomethacin showed an endothermic peak around its melting point. The liquisolid and physical mixture formulations showed the same peak in this area, which indicates that there is no interaction between the drug and excipients or changes in crystallinity of the drug during the formulation process. From the above finding it can be concluded that the enhanced dissolution rate of indomethacin liquisolid compacts is not due to the formation of a complex between the drug and excipients or any changes in crystallinity of the drug.

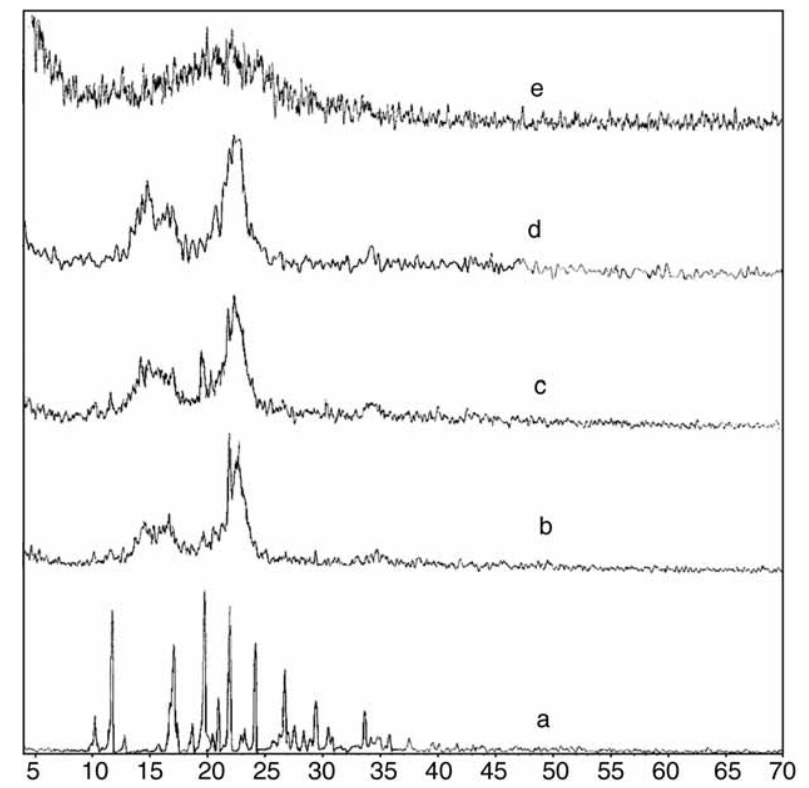

Fig. 2. X-ray powder diffractions of: a) indomethacin, b) liquisolid formulation, c) physical mixture of conventional formulation, d) Avicel, e) silica. 
Y. Javadzadeh et al.: Liquisolid technique as a tool for enhancement of poorly water-soluble drugs and evaluation of their physicochemical properties, Acta Pharm. 57 (2007) 99-109.

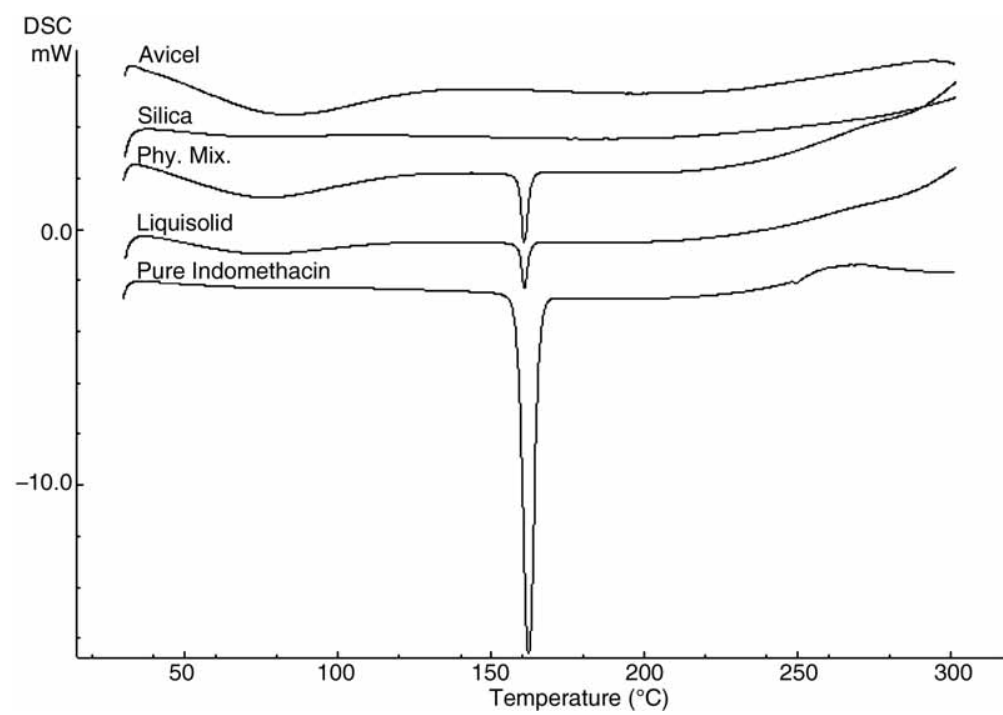

Fig. 3. Differential scanning calorimetery of silica, Avicel, indomethacin, physical mixture of a conventional formulation and liquisolid formulation.

In order to study the effect of aging on the hardness and dissolution profile of indomethacin liquisolid compacts, the best formulation (ILS-1, containing PG) was selected and 6 tablets from the ILS- 1 series were kept at $25^{\circ} \mathrm{C} / 75 \%$ relative humidity for a period of 12 months. Hardness and dissolution tests were then performed on these tablets. The results showed that the hardness of ILS- 1 tablets at the beginning and after 12 months were $45.2 \pm 2.9$ and $40.9 \pm 4.3 \mathrm{~N}(n=6)$, respectively, indicating that there was no significant difference between the hardness of fresh and aged tablets. Due to good compactibility of the produced liquid solid formulations, it is possible to prepare liquid solid compacts using high initial pressure to retain the hardness of final tablets in an acceptable range.

Fig. 4 shows the dissolution profile of freshly made liquisolid tablets and those stored for 12 months at $25{ }^{\circ} \mathrm{C} / 75 \%$ relative humidity. Respective $D E$ and $M D T$ data at $\mathrm{pH}$ 1.2 for the freshly made liquisolid compacts (ILS-1) were $35.8 \%$ and 9 min and for aged liquisolid tablets (ILS-1 aged) $37.2 \%$ and $8.1 \mathrm{~min}$ indicating no significant difference between two dissolution profiles. Similar results were obtained at pH 7.2 (Table II) indicating no significant difference between the freshly made liquisolid and aged liquisolid formulations in terms of their $D E$ and $M D T$ values. In order to confirm this conclusion, the similarity factor $\left(f_{2}\right)$ was calculated for freshly prepared ILS- 1 as a reference and the aged ILS- 1 as a test formulation. The $\mathrm{f}_{2}$ values were 77 and 95 for release at $\mathrm{pH} 1.2$ and 7.2 , respectively, indicating similar dissolution profiles before and after aging for the tablets at both $\mathrm{pH}$ values. We could expect that indomethacin liquisolid tablets maintained their initial fast releasing character even after 12 months storage.

It can be concluded that aging has no adverse effect either on the hardness of the indomethacin liquid solid compacts or on the dissolution profile. 
Y. Javadzadeh et al.: Liquisolid technique as a tool for enhancement of poorly water-soluble drugs and evaluation of their physicochemical properties, Acta Pharm. 57 (2007) 99-109.

a) $\quad$ Medium: SGF

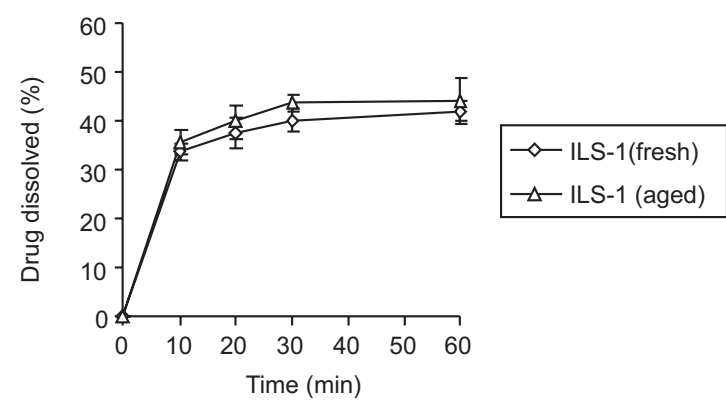

b) Medium: SIF

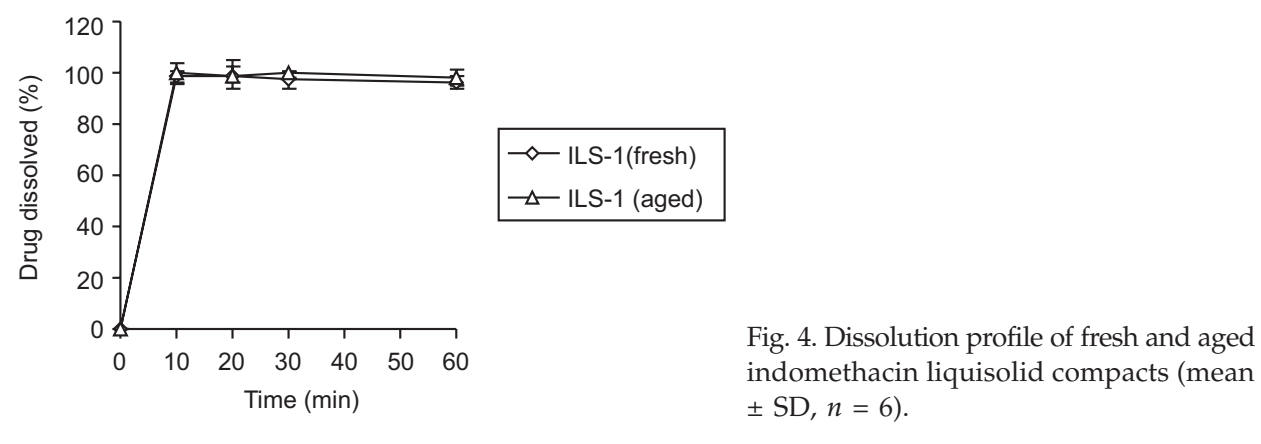

CONCLUSION

Liquisolid formulations were designed to contain liquid medications in powdered form, thereby possessing mechanisms of drug delivery similar to those of soft gelatin capsule preparations containing liquids. The results showed that the liquisolid technique could be a promising alternative technique to increase the dissolution of water insoluble drugs. The results of DSC and X-ray crystallography ruled out any changes in crystallinity of the drug or any interaction between the drug and exipients during the formulation process. It was shown that aging had no significant effects on dissolution profile of indomethacin liquisolid tablets.

\section{REFERENCES}

1. S. G. Kapsi and J. W. Ayres, Processing factors in development of solid solution formulation of itraconazole for enhancement of drug dissolution and bioavailability, Int. J. Pharm. 229 (2001) 193-203.

2. A. J. Aguiar, A. J. Zelmer and A. W. Kinkel, Deagglomeration behavior of relatively insoluble benzoic acid and its sodium salt, J. Pharm. Sci. 56 (1967) 1243-1252. 
Y. Javadzadeh et al.: Liquisolid technique as a tool for enhancement of poorly water-soluble drugs and evaluation of their physicochemical properties, Acta Pharm. 57 (2007) 99-109.

3. P. Finholt and S. Solvang, Dissolution kinetics of drugs in human gastric juice; the role of surface tension, J. Pharm. Sci. 57 (1968) 1322-1326.

4. S. L. Lin, J. Menig and L. Lachman, Interdependence of physiological surfactant and drug particle size on the dissolution behavior of water insoluble drugs, J. Pharm. Sci. 57 (1968) 2143-2146.

5. S. Spireas and S. Sadu, Enhancement of prednisolone dissolution properties using liquisolid compacts, Int. J. Pharm. 166 (1998) 177-188.

6. S. Spireas, S. Sadu and R. Grover, In vitro release evaluation of hydrocortisone liquisolid tablets, J. Pharm. Sci. 87 (1998) 867-872.

7. S. Spireas, T. Wang and R. Grover, Effect of powder substrate on the dissolution properties of methchrothiazide liquisolid compacts, Drug Dev. Ind. Pharm. 25 (1999) 163-168.

8. K. Y. Yang, R. Glemza and C. I. Jarowski, Effect of amorphous silicon dioxide on drug dissolution, J. Pharm. Sci. 68 (1979) 560-565.

9. C. Liao and C. I. Jarowski, Dissolution rates of corticoid solutions dispersed on silicas, J. Pharm. Sci. 73 (1984) 401-403.

10. A. Nokhodchi, Y. Javadzadeh, M. R. Siahi and M. Barzegar-Jalali, The effect of type and concentration of vehicles on the dissolution rate of a poorly soluble drug (indomethacin) from liquisolid compacts, J. Pharm. Pharm. Sci. 8 (2005) 18-25.

11. United States Pharmacopocia 26, Natural Formulary 21, USP Convention, Rockville 2003.

12. P. Costa, An alternative method to the evaluation of similarity factor in dissolution testing, Int. J. Pharm. 220 (2001) 77-83.

13. P. Costa and J. M. S. Lobo, Modelling and comparison of dissolution profiles, Eur. J. Pharm. Sci. 13 (2001) 123-133.

14. K. A. Khan, Concept of dissolution efficiency, J. Pharm. Pharmacol. 27 (1975) 48-49.

15. H. Abdou, Effect of the physicochemical properties of the drug on dissolution in Dissolution, Bioavailability and Bioequivalence (Ed. H. Abdou), Edison Mack Publishing Co., Easton, PA 1989, pp. 53-72.

16. N. Kaneniwa, M. Otsuka and T. Hayashi, Physicochemical characterization of indomethacin polymorphs and transformation kinetics in ethanol, Chem. Pharm. Bull. 33 (1985) 3447-3455.

17. H. Imaizumi, N. Nambu and T. Nagai, Stability of several physical properties of amorphous and crystalline forms of indomethacin, Chem. Pharm. Bull. 28 (1980) 2565-2569.

18. L. Borka, Polymorphism of indomethacin. New modifications, their melting behavior and solubility, Acta Pharm. Suecica 11 (1974) 295-303.

19. M. Otsuka, F. Kato and Y. Matsuda, Determination of indomethacin polymorphic contents by chemometric near-infrared spectroscopy and conventional powder X-ray diffractometry, Analyst 126 (2001) 1578-1582.

20. M. Yoshioka, B.C. Hancock and G. Zografi, Crystallization of indomethacin from the amorphous state below and above its glass transition temperature, J. Pharm. Sci. 83 (1994) 1700-1705.

21. H. Imaizumi, N. Nambu and T. Nagai, Stabilization of amorphous state of indomethacin by solid dispersions in polyvinylpyrolidone, Chem. Pharm. Bull. 31 (1983) 2510-2512. 
Y. Javadzadeh et al.: Liquisolid technique as a tool for enhancement of poorly water-soluble drugs and evaluation of their physicochemical properties, Acta Pharm. 57 (2007) 99-109.

$S A \check{Z} E T A K$

\section{Tekućinsko-čvrsti pripravci kao sredstvo za evaluaciju i poboljšanje fizičkokemijskih svojstava teško topljivih lijekova}

YOUSEF JAVADZADEH, MOHAMMAD REZA SIAHI, SOLMAZ ASNAASHARI i ALI NOKHODCHI

U radu je ispitivan učinak tekućinsko-čvrstih sustava na poboljšanje oslobađanja u vodi netopljivih tvari (indometacina). Koristeći različita nehlapljiva otapala pripravljeno je nekoliko tekućinsko-čvrstih tableta, a zatim je proučavan učinak starenja na oslobađanje indometacina. Moguće interakcije između indometacina i drugih komponenata praćene su difrakcijom rentgenskih zraka na praškastom uzorku (XPD) i diferencijalnom pretražnom kalorimetrijom (DSC). Oslobađanje je praćeno pri dva različita $\mathrm{pH}, 1,2$ i 7,2, simulirajući uvjete u želučanoj ili crijevnoj tekućini. Rezultati pokazuju da je profil oslobađanja iz tekućinsko-čvrstih pripravaka značajno bolji pri pH 1,2 ili 7,2, u usporedbi s pripravcima dobivenim kompresijom. Poboljšanje oslobađanja indometacina iz tekućinsko-čvrstih pripravaka posljedica je povećanog vlaženja površine čestica ljekovite tvari. Da bi se proučio učinak starenja na čvrstoću pripravaka i oslobađanje ljekovite tvari, tekućinsko-čvrsti pripravci su uskladišteni 12 mjeseci na $25^{\circ} \mathrm{C} / 75 \%$ relativne vlažnosti. Rezultati ukazuju da starenje nema značajni učinak na profil oslobađanja. Pripravci s propilenglikolom imaju bolji profil oslobađanja nego pripravci s istom koncentracijom PEG 400 ili Tween 80. DSC i XPD pokazuju da nije došlo do promjene kristaliničnosti niti do interakcije između indometacina i pomoćnih tvari (Avicel i silikagel) za vrijeme izrade pripravaka.

Ključne riječi: indometacin, tekućinsko-čvrsti pripravci, profil oslobađanja, starenje, DSC, XPD

Drug Applied Research Center and Faculty of Pharmacy, Tabriz University of Medical Sciences, Iran

Medway School of Pharmacy, Central Ave., University of Kent and Greenwich, Chatham, Kent, ME4 4TB, United Kingdom 